\title{
IMPLEMENTATION OF THE SELECTIVE STRATEGY OF STATE REGULATION OF THE LABOUR MARKET IN TERMS OF MONOPROPELLANT SITE (ON EXAMPLE OF THE CHISTOPOLSKY MUNICIPAL AREA)
}

Irina V. Yusupova ${ }^{1}$

Leilia R. Kadyrova ${ }^{2}$

\begin{abstract}
The article is devoted to the implementation of selective (mixed) strategy of state regulation of the labor market in terms of monopropellant areas, involving constant monitoring of the labor market areas, the adoption of operational measures in the field of reducing unemployment and increasing employment, as well as selective screening workforce. In conditions of non-diversified economy of the territory the problems of employment and unemployment are particularly acute and require an additional set of measures to reduce labor market difficulties. The state regulation of the labor market in the Russian Federation in terms of providing employment and reducing the overall and registered unemployment rates has more than a 25-year history. Effective
\end{abstract}

organization of public works, as well as vocational training and training of unemployed citizens, including disabled people, persons without a profession, as well as women with children under the age of 3 years, is an established activity aimed at practically guaranteed employment of these categories of people. At the same time, an effective mechanism for implementing selective (mixed) strategies is the outstripping training of people who are at risk of mass dismissal (lockout) from enterprises and organizations.

Keywords: human capital, labour resources, a selective strategy, government regulation, labor market, human resources, non-diversified territory, Chistopol'.

\footnotetext{
${ }^{1}$ Kazan Federal University, The Ministry of Economy of the Republic of Tatarstan, Kazan, Russia. E-mail: I.Yusupova@tatar.ru

2 Kazan Federal University, Republic of Tatarstan, Kazan, Russia.Email:leilia.kadyrova@gmail.com
} 


\section{Introduction}

Planning and tactical support of the formation and implementation process of state regulation, as well as the entire strategic management system, must proceed from certain principles. Among them: the principle of targeted diversification; the principle of public policy institutionalization; the principle of financial security solutions optimization; the principle of personnel inventory; the principle of information support of public policy objectives; principle of accounting redistributive activity; the principle of feedback [8].

Based on studies of municipalities that have features of nondiversified municipality, it is revealed that one of the top problems is shortage of qualified personnel [7].

Achievement of economic efficiency of goods and services production and effectiveness of state governance directly determined by the quantity and quality of human capital. They, in turn, are conditioned by quality of the education, culture and health of previous generations. They are built up through the accumulation of knowledge, experience, skills of people. Without an effective system of human development, which, in turn, is the education system, it is impossible to achieve a high level of competitiveness in the global competition of economic systems.

A number of scholars confirm the importance of personnel potential modernization. The work of those "personnel", "people", "workers" only creates all the objects of value. In this sense, people not only make all the difference, they still create it. People are the main and the only value in the economy [9].

\section{Materials and methods}

The study of the human capital and possibilities of its development and use in modernization breakthrough of the next decade is an important task of analytical expert observation. This observation is used to assess economic changes, to develop trends and the accumulation of human capital in the Republic of Tatarstan. Tatarstan as a region that has achieved considerable success in the modernization of the economy, has to fulfill the challenge of achieving new social and economic development to obtain a leading position in the international arena. Today, in conditions when non-diversified municipalities thanks to the support of 
the Government of the Russian Federation have received such powerful tools as the «Territories of rapid socioeconomic development» (hereafter TRD), there is every reason to believe that the Republic of Tatarstan is preparing four more applications to Chistopol', Nizhnekamsk, Mendeleevsk, Zelenodolsk also receive the status of TRD. It should be noted that the Republic of Tatarstan is traditionally in charge of this process and received the first TRD in Russia (in Naberezhnye Chelny). The acquisition of TRD status by the mentioned territories will require the inflow of highly qualified personnel, since the growth of investment activity will be followed by industrial growth, conditioned by the development of existing ones and the emergence of new industries. Therefore, it is necessary to determine in a timely manner:

- the main challenges in the field of training, recruitment, retention, and use of personnel for the new economy of non-diversified municipality (on the example of the Chistopolsky municipal district);

- the possibilities and conditions for creating, attracting and developing human potential for the transition to the new economy;
- the possibility of converting human potential into human capital.

This requires:

- to analyze the situation on priority directions of education, healthcare and culture development in Chistopol' municipal district;

- to analyze the situation in the field of migration of skilled personnel (as well as talented youth) in and from Chistopol';

- to identify the potential for improving the situation in these areas and formulate appropriate public policy objectives;

- to identify the objectives of public policy, which are required to implement in order to achieve the stated goals;

- to define a set of target indicators for the achievement of goals and objectives.

\section{RESULTS}

An active policy in the field of employment has been conducted in the Republic of Tatarstan. However it is insufficient, taking into account the ambitious development goals of the Republic. Their achievement will reinforce the existing gaps between supply and demand on the labour market. In the next 10 to 15 years in Tatarstan, as well as throughout the country, there will be a worsening of the demographic situation and the decrease of the 
population of working age. In the future, the Republic of Tatarstan will have to solve complex tasks of employment modernization by improving the competitiveness of the population, attraction of highly skilled migrants in the innovative sectors of the economy, increasing mobility of the population of the Republic and the optimization of territorial proportions of employment in different types of settlements with the aim of innovative development of major cities, staffing for industrial development and preservation of economically viable village [1]

The main challenges:

- the increase of competition in the Russian regions for human resources that requires raising the attractiveness and competitiveness of the labour market of the Republic of Tatarstan;

- the tendency of changing several professions during life;

- the low quality of human capital in the republic: a formal "re-education" with a low quality of education;

- the institutional trap of the average premium for higher education and living conditions ratio. On the one hand, the Republic of Tatarstan lags behind from regions in which specialists with higher education can receive large incomes, on the other hand, from regions that with smaller increments of income from higher education, provide better living conditions. Accordingly, there is migration to other regions, where wages are higher and the working and living conditions are better;

- structural imbalances in the labor market: a shortage of skilled industrial workers and technical specialists, as well as high-tech specialists required for priority innovative directions of development of the Republic of Tatarstan;

- low territorial mobility of the population, necessary to reduce the imbalance of demand and supply on the local labour markets and employment efficiency;

- significant scale of the "gray" labor market, a high share of informal incomes;

- decrease of the population of working age

- a large flow of illegal migrant workers;

- low unemployment rate, but the exit from unemployment is aimed at economic inactivity, especially among women;

- high inequality in the distribution of income, which is not transformed into 
investment and new jobs (in stagnation this challenge is exacerbated);

- insufficient interest of employers in investment in training and retraining;

- increase the portion of social payments in the revenue structure;

- the absence of a mechanism that accounts the income of citizens who do not accept job offers for vacant positions and have no reason not to be employed;

- orientation of the social benefits system mainly to the elderly people, although the maximum risks of poverty is among children [1].

Chistopol' is a town with a highly promising potential where new and expand existing production is created. Here the development of highly qualified specialists is a priority. The personnel training starts at school. In this regard, career - oriented programs have been created. They allow high school students to try themselves in a particular specialty and to develop the necessary skills.

In the system of professional education there are two institutions of secondary and three institutions of higher education. Higher education institutions in Chistopol' are: Chistopol' branch of the "Kazan National Research Technical University named after A. N. Tupolev", Chistopol' branch of "Kazan
(Volga region) Federal University", and Chistopol' branch of private educational institution of higher professional education "Institute of economics, management and law" (Kazan)[3].

Chistopol' branch of the "Kazan National Research Technical University named after A. N. Tupolev" is recruiting students in four areas of study by intramural form: "Engineering", "Computer science", "Economics", "Management", and also have the opportunity to obtain additional education "Translator in the sphere of professional communication (English language)".

At the site of Executive Committee of Chistopol' municipality a meeting with the representatives of Chistopol' branch of the "Kazan National Research Technical University named after A. N. Tupolev" was held. The representatives of Kazan state Power Engineering University and of Moscow Institute of Physics and Technology ware suggested that "Electronics" and "Robotics and mechatronics" specialties inclusion to the List of popular professions and specialties, corresponding to priority directions of economy development of 
the Republic of Tatarstan for the period 2018-2024 years. [4].

Currently, the Chistopol' branch of the "Kazan (Volga region) Federal University" is training specialists and bachelors in intramural and extramural form of study in 5 areas of training:

"Construction",

"Environmental

Engineering and Water Use", "Operation of Transport-Technological Machines and Complexes", "Economics", "State and municipal management".

Table 1: The number of graduates of educational institutions of higher education, secondary-level and basic vocational education in 2011-16

\begin{tabular}{|c|c|c|c|c|c|c|c|}
\hline \multirow{2}{*}{ Name } & & & & & & & \multirow{2}{*}{ Total: } \\
\hline & 2011 & 2012 & 2013 & 2014 & 2015 & 2016 & \\
\hline $\begin{array}{l}\text { Kazan National Research } \\
\text { Technical University } \\
\text { named after A. N. Tupolev }\end{array}$ & 201 & 227 & 215 & 175 & 182 & 142 & 1142 \\
\hline Kazan Federal University & 306 & 348 & 175 & 193 & 335 & 246 & 1603 \\
\hline $\begin{array}{l}\text { Institute of economics, } \\
\text { management and law }\end{array}$ & 217 & 308 & 169 & 138 & 152 & - & 983 \\
\hline $\begin{array}{l}\text { State Educational } \\
\text { Budgetary Institution of } \\
\text { the Basic Vocational } \\
\text { Education "Professional } \\
\text { School № 72" }\end{array}$ & 238 & 153 & 140 & 82 & 48 & - & 661 \\
\hline $\begin{array}{l}\text { State Autonomous } \\
\text { Educational Institution of } \\
\text { the Secondary-level } \\
\text { Vocational Education } \\
\text { «Chistopol' Polytechnic } \\
\text { College» }\end{array}$ & 47 & 239 & 131 & 164 & 126 & - & 707 \\
\hline $\begin{array}{l}\text { State Autonomous } \\
\text { Educational Institution of } \\
\text { the Secondary-level }\end{array}$ & 40 & 65 & 136 & 82 & 93 & - & 416 \\
\hline
\end{tabular}




\begin{tabular}{|l|l|l|l|l|l|l|l|}
\hline $\begin{array}{l}\text { "Chistopol Pedagogical } \\
\text { College" }\end{array}$ & & & & & & & \\
\hline $\begin{array}{l}\text { State Autonomous } \\
\text { Professional Educational } \\
\text { Institution "Chistopol" } \\
\begin{array}{l}\text { multidisciplinary college" } \\
\text { (united in one college) }\end{array}\end{array}$ & - & - & - & - & - & 227 & 227 \\
\hline
\end{tabular}

In the branches of Kazan National Research Technical University named after A. N. Tupolev, Kazan Federal University and Institute of economics, management and law there is a target training of specialists for certain region companies. The training involves both learning and the students passing practice, as well as their future employment. A large number of graduates were employed at such companies as Manufacturingcommercial company "BETAR" Limited (MCC BETAR Ltd.), Science and Technical Center "Vostok" LLC, etc. At the same time, the graduates of these universities are highly valued and in demand not only in Chistopol' and the republic, but also in Russia.

At the same time, vocational retraining of the population is actively carried out at the expense of the Employment Service. That is why the list of specialties is expanding and that significantly increases the educational potential of the population [5].

By 2018, the number of work places, that is planned to create in the TRD Chistopol', will have been increasing to 1100 . This staff requirement can be covered by graduates of higher educational institutions, whose number is more than 384 people per year, and by those people who applied to the Employment Center, whose number in 2016 was 250 people.

In the further table there is the forecast of the minimum number of new permanent work places that are planned to be created in TRD Chistopol' as a result of investment projects implementation by the residents (in the context of OKVED, Russian Classification of Economic Activities). In the forecast we also take into account the statistics of the number of workplaces for the similar investment projects being implemented and planned 
for implementation in the region.

Table 2:The forecast of the number of work places as the result of implementation of investment projects of the residents in TRD Chistopol' up to 2018

\begin{tabular}{|c|c|c|c|}
\hline № & $\begin{array}{l}\text { Name of the initiator's } \\
\text { company }\end{array}$ & Brief description of the project & $\begin{array}{c}\text { The number } \\
\text { of work } \\
\text { places }\end{array}$ \\
\hline 1 & $\begin{array}{c}\text { Manufacturing group } \\
\text { OOO «Delrus Chistopol'» } \\
\text { a limited liability } \\
\text { company under the laws } \\
\text { of Russian Federation }\end{array}$ & $\begin{array}{l}\text { «Chistopol' plant of infusion } \\
\text { solutions» }\end{array}$ & 92 \\
\hline 2 & $\begin{array}{c}\text { OOO «Tatremstroj» } \\
\text { a limited liability } \\
\text { company under the laws } \\
\text { of Russian Federation }\end{array}$ & $\begin{array}{l}\text { «Construction of the Chistopol’ } \\
\text { plant for the production of heat- } \\
\text { insulated urethane-foam pipes» }\end{array}$ & 52 \\
\hline 3 & $\begin{array}{c}\text { OOO «Novye } \\
\text { tekhnologii» } \\
\text { a limited liability } \\
\text { company under the laws } \\
\text { of Russian Federation }\end{array}$ & $\begin{array}{l}\text { Expansion of the foundry of LLC } \\
\text { Manufacturing company " Novye } \\
\text { tekhnologii" }\end{array}$ & 50 \\
\hline 4 & $\begin{array}{c}\mathrm{OOO} \ll \text { Diotekh» } \\
\text { a limited liability } \\
\text { company under the laws } \\
\text { of Russian Federation }\end{array}$ & $\begin{array}{l}\text { «Construction of a plant for the gas } \\
\text { meters production» }\end{array}$ & 60 \\
\hline 5 & $\begin{array}{l}\text { OOO «Biotekhnologii» } \\
\text { a limited liability } \\
\text { company under the laws } \\
\text { of Russian Federation }\end{array}$ & $\begin{array}{l}\text { «Production of protein concentrate } \\
\text { from oilseeds» }\end{array}$ & 142 \\
\hline
\end{tabular}




\begin{tabular}{|c|c|c|c|}
\hline 6 & $\begin{array}{c}\mathrm{OOO} \text { «Neptun» } \\
\text { a limited liability } \\
\text { company under the laws } \\
\text { of Russian Federation }\end{array}$ & $\begin{array}{l}\text { Organization of production and } \\
\text { sales of mechanical alarms }\end{array}$ & 48 \\
\hline 7 & $\begin{array}{c}\text { OOO «Metallstroj» } \\
\text { a limited liability } \\
\text { company under the laws } \\
\text { of Russian Federation }\end{array}$ & $\begin{array}{l}\text { Manufacture of metal structures } \\
\text { (doors) }\end{array}$ & 22 \\
\hline 8 & $\begin{array}{c}\text { OOO Production and } \\
\text { Commercial Firm «Kama } \\
\text { Plast» } \\
\text { a limited liability } \\
\text { company under the laws } \\
\text { of Russian Federation }\end{array}$ & $\begin{array}{l}\text { Organization of plastic products } \\
\text { production by injection molding }\end{array}$ & 29 \\
\hline 9 & $\begin{array}{c}\text { OOO «FtizisBioMed» } \\
\text { a limited liability } \\
\text { company under the laws } \\
\text { of Russian Federation }\end{array}$ & $\begin{array}{l}\text { Production of telemedicine mobile } \\
\text { fluorographic complexes with } \\
\text { satellite communication channels } \\
\text { and automated reading of } \\
\text { fluorograms }\end{array}$ & 30 \\
\hline 10 & $\begin{array}{c}\text { AO RK «Vector» } \\
\text { a company limited by } \\
\text { shares under the laws of } \\
\text { Russian Federation }\end{array}$ & $\begin{array}{l}\text { Production of control and } \\
\text { communications mobile systems } \\
\text { on the basis of satellite reflector } \\
\text { antennas } \mathrm{Ku} / \mathrm{Ka} \text {-bands for the } \\
\text { Emergency Situations Ministry, } \\
\text { Ministry of Internal Affairs, oil and } \\
\text { gas companies etc. }\end{array}$ & 15 \\
\hline 11 & $\begin{array}{l}\text { OAO «Cpistopol'skij } \\
\text { hlebozavod» a publicly } \\
\text { held company under the } \\
\text { laws of the Russian } \\
\text { Federation }\end{array}$ & Manufacture of muesli & 55 \\
\hline
\end{tabular}




\begin{tabular}{|c|c|c|c|}
\hline 12 & $\begin{array}{c}\mathrm{OOO} \ll \text { Kvest» } \\
\text { a limited liability } \\
\text { company under the laws } \\
\text { of Russian Federation }\end{array}$ & $\begin{array}{l}\text { Manufacture of power supplies and } \\
\text { drivers for LED lighting fixtures }\end{array}$ & 20 \\
\hline 13 & $\begin{array}{c}\text { OOO «Pluton» } \\
\text { a limited liability } \\
\text { company under the laws } \\
\text { of Russian Federation }\end{array}$ & $\begin{array}{l}\text { Production of Time relays of series } \\
\text { PB 100, PB } 200\end{array}$ & 20 \\
\hline 14 & $\begin{array}{c}\mathrm{OOO} \ll \text { Galant» } \\
\text { a limited liability } \\
\text { company under the laws } \\
\text { of Russian Federation }\end{array}$ & Manufacture of hydraulic tools & 20 \\
\hline 15 & $\begin{array}{c}\mathrm{OOO} \ll \mathrm{TNP} » \\
\text { a limited liability } \\
\text { company under the laws } \\
\text { of Russian Federation }\end{array}$ & $\begin{array}{l}\text { The production of consumer goods } \\
\text { from plastic }\end{array}$ & 20 \\
\hline 16 & $\begin{array}{c}\text { OOO «Novator» } \\
\text { a limited liability } \\
\text { company under the laws } \\
\text { of Russian Federation }\end{array}$ & $\begin{array}{l}\text { Production of the granulated } \\
\text { organic fertilizers }\end{array}$ & 18 \\
\hline 17 & $\begin{array}{c}\text { OOO «Sapfir» } \\
\text { a limited liability } \\
\text { company under the laws } \\
\text { of Russian Federation }\end{array}$ & Production of technical stones & 10 \\
\hline 18 & $\begin{array}{c}\text { OOO «Gazprom } \\
\text { gazomotornoe toplivo» } \\
\text { a limited liability } \\
\text { company under the laws } \\
\text { of Russian Federation }\end{array}$ & $\begin{array}{l}\text { «Construction of a natural gas } \\
\text { liquefaction complex» }\end{array}$ & 60 \\
\hline 19 & $\begin{array}{l}\text { OOO «Alkotorg» } \\
\text { a limited liability }\end{array}$ & $\begin{array}{l}\text { «Construction of a logistics center } \\
\text { on the territory of IP «Chistopol'» }\end{array}$ & 129 \\
\hline
\end{tabular}




\begin{tabular}{|c|c|l|c|}
\hline & $\begin{array}{c}\text { company under the laws } \\
\text { of Russian Federation }\end{array}$ & & \\
\hline 20 & $\begin{array}{c}\text { AO «Tatspirtprom» } \\
\text { a company limited by } \\
\text { shares under the laws of } \\
\text { Russian Federation }\end{array}$ & $\begin{array}{l}\text { Construction of a beer production } \\
\text { plant }\end{array}$ & 300 \\
\hline 21 & $\begin{array}{c}\text { OOO TPK «Tatpolimer» } \\
\text { a limited liability } \\
\text { company under the laws } \\
\text { of Russian Federation }\end{array}$ & $\begin{array}{l}\text { Running a plant for casting } \\
\text { aluminum alloys and a plastic }\end{array}$ & \\
& injection molding plant & \\
\hline & & & $\mathbf{1 3 4 2}$ \\
\hline
\end{tabular}

\section{Conclusion}

We came to the conclusion that, due to the planned association of graduates of educational institutions in the Chistopolsky municipality for the period up to 2018, and the real needs of potential employers in TRD Chistopol' in the context of professions that are in demand in the implementation of investment projects until 2018, we can predict a shortage of labor resources that can be a tangible strategic problem.

Solutions of this problem are in programs of joint training of demanded specialists by educational institutions of all levels of education and companies, i.e. in the interaction at the stage of organization of educational process in training directly at the enterprise (internships, practice), monitoring of the labor market with the aim of identifying redundant at the moment, and in worker who want to go the programs of professional retraining at the expense of the Employment Service.

\section{Discussion}

Almost for thirty years of the state Employment Service functioning, experience in reducing tension in the labor market has been accumulated. Moreover, a sustained effect from the implementation of these activities has been achieved through an effective employment policy. At the same time, it should be noted that this toolkit practically does not change despite the fact that there is a worthy foreign experience. So, in our opinion, it would 
be advisable to learn from the Sweden experience:

- stimulating small and family business under the best possible conditions by state subsidies and loans, through which start-up capital can be provided to owners of only $10 \%$, to $70 \%$ - government grants and 20\% loans. If the company is not profitable, then 4 years it is exempt from tax [11];

- ensuring the geographical mobility of the population and the workforce by providing subsidies and loans for moving with families from areas with an excess of labor to areas where there are vacant places, with a guarantee of improving housing and possibly material conditions [11];

- providing every job seeker with complete information about vacancies by professions, industries and regions of the country and the creation of accessible data banks for this purpose;

- payment of all types of connection services with the personnel departments of enterprises[11];

- the organization of public works, mainly for young people, on the houses and roads building, in the service sector for up to 6 months with guaranteed earnings within $50-100 \%$ of the average salary for this position [11];
- work financing in private young firms by providing subsidies to business owners within half a year in the form of paying $50 \%$ of the costs for newly created workplaces [11];

- special technical equipment at workplaces in enterprises for disabled people and payment of subsidies to business owners for the reception of disabled people for work and partly for their wages [11];

- stimulating the expansion of business and overtime, and thereby more full employment by reducing taxation from profits and personal income.

\section{Acknowledgments}

The work is performed according to the Russian Government Program of Competitive Growth of Kazan Federal University.

\section{Reference}

The law of the Republic of Tatarstan from June 17, 2015 No. 40-ZRT «On approval of strategy of social-economic development of the Republic of Tatarstan till 2030».

The Cabinet of Ministers of the Republic of Tatarstan from 28.03.2017, №593-p 
«List of popular professions and specialties, corresponding to priority directions of development of economy of the Republic of Tatarstan for the period 2018-2024 years».

Strategy for socio-economic development in Chistopol' municipal district up to 2030. - [Electronic resource]. Mode доступа:http://mert.tatarstan.ru/rus/strat egii-sotsialno-ekonomicheskogorazvitiya.htm.

Kilchevsky N. R., Strogovich M. I. Development of the mechanism of interaction of universities and enterprises is an objective need of the XXI century. - Ekaterinburg: GOU USTU-UPI, 2002.-P. 37-38.

Lubovni V. Y., Pchelintsev O. S., Herzberg, L. J., and others. Series «Library of the municipal employee» Vol.5.-M., 1998.-95 C.

Pyankova S. G. Institutions strategic development of not diversified territories. - Ekaterinburg: Institute of Economics UB RAS. 2013257 p.
Pyankova S. G. prospects for the development and growth of not diversified territories in the Russian Federation. - Ekaterinburg: Institute of Economics UB RAS. 2014 - 173 C.

Yakunin V. I., the Formation of public policy in modern Russia: problems of theory and practice. - M.: ROSSPEN, 2006.

Bossidy Larry. In the end everything is decided by people, not strategies. [Electronic resource]. - Mode of access: http://fictionbook.ru/static/trials/04/36/8 2/04368235.a6.pdf

Regional'nye aspekty sovershenstvovaniya gosudarstvennoj politiki zanyatosti / I. V. YUsupova M.: Ekon-Inform, 2015.

Gendler G., Gil'dingersh M. Social'nye posledstviya bezraboticy // Chelovek i trud. 2006. № 3. - S.47-49 